\title{
Microarrays for the Detection of HBV and HDV
}

\author{
Sun Zhaohui ${ }^{\dagger, *}$, Zheng Wenling ${ }^{\dagger}$, Zhang Bao ${ }^{\ddagger}$, Shi Rong and MA Wenli”** \\ 'Institute of Molecular Oncology, General Hospital of Guangzhou Command, Guangzhou 510010, P. R. China \\ ${ }^{\ddagger}$ Institute of Molecular Biology, First Military Medical University, Guangzhou 510515, P. R. China
}

Received 15 January 2004, Accepted 17 February 2004

The increasing pace of development in molecular biology during the last decade has had a direct effect on mass testing and diagnostic applications, including blood screening. We report the model Microarray that has been developed for Hepatitis B virus (HBV) and Hepatitis D virus (HDV) detection. The specific primer pairs of PCR were designed using the Primer Premier 5.00 program according to the conserved regions of $\mathrm{HBV}$ and HDV. PCR fragments were purified and cloned into pMD18-T vectors. The recombinant plasmids were extracted from positive clones and the target gene fragments were sequenced. The DNA microarray was prepared by robotically spotting PCR products onto the surface of glass slides. Sequences were aligned, and the results obtained showed that the products of PCR amplification were the required specific gene fragments of HBV, and HDV. Samples were labeled by Restriction Display PCR (RD-PCR). Gene chip hybridizing signals showed that the specificity and sensitivity required for $\mathrm{HBV}$ and $\mathrm{HDV}$ detection were satisfied. Using PCR amplified products to construct gene chips for the simultaneous clinical diagnosis of $\mathrm{HBV}$ and HDV resulted in a quick, simple, and effective method. We conclude that the DNA microarray assay system might be useful as a diagnostic technique in the clinical laboratory. Further applications of RD-PCR for the sample labeling could speed up microarray multi-virus detection.

Keywords: Diagnosis, Gene probe, HBV, HCV, Microarray, PCR

\section{Introduction}

Viral hepatitis is the most common cause of acute and chronic hepatitis. The term viral hepatitis generally refers to infections

*To whom correspondence should be addressed.

Tel: 86-20-61648210,36622203; Fax: 86-20-61647755, 36622203

E-mail: wenli@fimmu.edu.cn resulting from one of the hepatotrophic viruses. Chronic infection by the hepatitis virus affects over 500 million people worldwide (Lok et al., 2001), is associated with significant morbidity and mortality, and is considered a major public health problem in most areas of the world, which raises issues of its diagnosis, treatment, and prevention (Jay et al., 1997). Hepatitis B and D viruses are parent rally transmitted, and occur both in the acute and chronic forms. When they persist in a chronic carrier state, they serve as a reservoir for infection and give rise to chronic hepatitis, cirrhosis, and hepatocellular carcinoma (HCC). In particular, the laboratory diagnosis of viral hepatitis is important to effectively plan immediate patient management, to determine treatment choices, and to limit the transmission of infection.

In the past decade, improvements in molecular biologybased techniques have yielded highly valuable tools for use in this setting. DNA microarray technology can allow the quantitative and simultaneous analysis of hundreds to thousands of genes (Schena et al., 1995; Schena et al., 1996; Shalon et al., 1996), and allows the high-throughput screening of multiple pathogens in a large numbers of samples. The DNA chip represents a new category of this developing technology, and is characterized by expedient, large scale, highly automatic, and sensitive detection of biological information regarding DNA and RNA.

In this article, we describe a microarray technology developed for the simultaneous detection of HBV and HDV. The specific PCR primers used were designed using the Primer Premier 5.00 program according to the conserved regions of HBV and HDV. The PCR fragments were purified and cloned into pMD18-T vectors. Recombinant plasmids were extracted from positive clones and the target gene fragments were sequenced. The DNA microarrays were then prepared by robotically spotting PCR products onto the surfaces of glass slides.

\section{Materials and Methods}

Probe template The full-length plasmid of HDV pDL553 was 
presented by Dr S. Gudima of the Fox Chase Cancer Center (USA), and the full-length HBV plasmid was constructed in our laboratory.

Chemicals and reagents Premix Taq, dNTP, EcoRI, Sau3AI, pMD18-T vector, and T4 DNA Ligase were obtained from Takara Co. (Shiga, Japan). Plasmid Miniprep kits were purchased from Shen Neng Bo Cai Co. (China), PCR primers of HBV and HDV and the primers in pMD18-T vector were synthesized by BIOASIA Co. (China). The universal primer cy5-GTTTGGCTGGTGTGGATC was purchased from Gibco Co. (Gaithersburg, USA), CMT-GAPS coated glass slides were from Corning Co. (Corning, USA).

Bacterial strains The E. coli strain XL-1 used in these experiments was maintained in our laboratory.

Oligonucleotide primers design Oligonucleotide primers were designed using the Primer Premier 5.00 program and GenBank Blastn sequence alignments. Selected PCR primers met the following criteria: (i) primers hybridized to highly conserved sequence elements, (ii) each amplicon spanned approximately 250$700 \mathrm{bp}$, (iii) primer melting points generally fell between 50 and $54^{\circ} \mathrm{C}$. We designed 10 and 4 primer pairs respectively according to the conserved region of HBV and HDV. The sequences of the synthetic primers used in the study are shown in Table 1 .

PCR The plasmids of HBV and HDV $(1 \mu \mathrm{l})$, respectively, were added to a PCR mixture of total volume $50 \mu$ l containing $25 \mu \mathrm{l}$ $2 \times$ premix, and $2 \mu \mathrm{l}$ (each) of the oligonucleotide primers $(0.25 \mu \mathrm{M})$.

HBV The mixture was denatured at $94^{\circ} \mathrm{C}$ for $5 \mathrm{~min}$ and then subjected to 30 thermal cycles $\left(94^{\circ} \mathrm{C}\right.$ for $55 \mathrm{~s}, 55^{\circ} \mathrm{C}$ for $55 \mathrm{~s}, 72^{\circ} \mathrm{C}$ for $55 \mathrm{~s}$ ), followed by a final $5 \mathrm{~min}$ incubation at $72^{\circ} \mathrm{C}$.

HDV The mixture was denatured at $94^{\circ} \mathrm{C}$ for $5 \mathrm{~min}$ and then subjected to 30 thermal cycles $\left(94^{\circ} \mathrm{C}\right.$ for $45 \mathrm{~s}, 50^{\circ} \mathrm{C}$ for $45 \mathrm{~s}, 72^{\circ} \mathrm{C}$ for $60 \mathrm{~s}$ ), followed by a final $5 \mathrm{~min}$ incubation at $72^{\circ} \mathrm{C}$. The mixture was then chilled and the products were sized by $1.5 \%$ agarose gel electrophoresis. The PCR products were purified, using a 3S PCR product purification kit V20 (Bocai Corp., Shanghai, China) and stored at $-20^{\circ} \mathrm{C}$.

Identification of the PCR products After purification using the PCR product purification kit, the PCR products were inserted into pMD18-T vector. The ligation mixture which contained $4 \mu \mathrm{l} \mathrm{PCR}$ products, $1 \mu \mathrm{l}$ pMD18-T vector $(50 \mathrm{ng} / \mu \mathrm{l})$, and $5 \mu \mathrm{l}$ loading buffer solution was incubated for 4 hours at $16^{\circ} \mathrm{C}$, and then transferred into $100 \mu \mathrm{l}$ XL-1 E. coli competent cells, which had been previously treated with solutions containing $\mathrm{Ca}^{2+}$ ions $(0.1 \mathrm{M})$. To transform $E$. coli, the mixture of DNAs formed in the ligation reaction was combined with a suspension of competent cells for $30 \mathrm{~min}$, then heat-shocked at $42^{\circ} \mathrm{C}$ for $1 \sim 2 \mathrm{~min}$. The cells were then incubated in a growth medium and finally spread on an agar plate and incubated until single colonies of bacteria grew. Clones containing target fragments were then selected and identified with pMD18-T vector primer (primerA5'-CTAAAACGACGGCC AGT-3', primer B 5'CAGGA AACAGCTATGAC-3'). The sequence of target fragments were then analyzed using an ABI PRISMTM 377 DNA sequencer, and GenBank Blastn sequence alignments were performed.

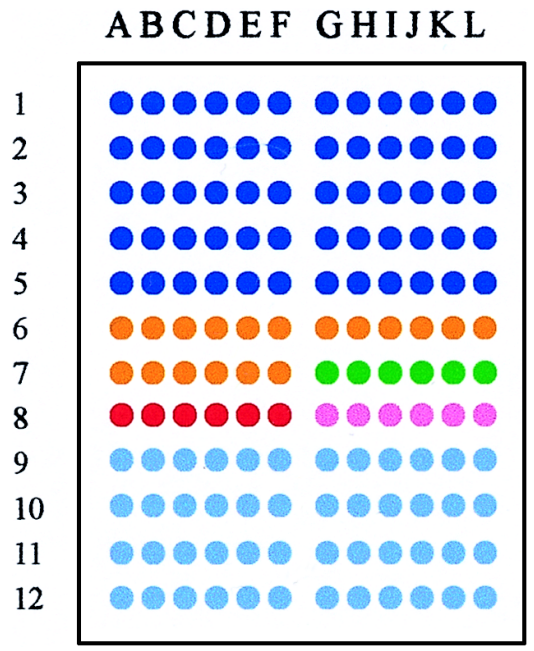

Fig. 1. Arrangment of all spots on genechip. HBV probes(10 fragments of genes) Negative control Empty controls HBV Positive controls HDV Positive controls HDV probes (4 fragments of genes).

Microarray printing and processing The final concentration of each purified PCR product was adjusted to $0.3 \mathrm{mg} / \mathrm{ml}$ with DMSO and water $(50 \% \mathrm{v} / \mathrm{v})$. The DNA microarray was prepared by spotting the PCR products on special glass slides using a Cartesian 5,500 MicroArrayer. The DNAs of the target gene were then crosslinked with ultraviolet irradiation, baked at $80^{\circ} \mathrm{C}$ for $2 \mathrm{~h}$, and maintained in closed containers until application. The arrangement of spots on the gene chip is shown in Fig. 1.

Samples labeling The plasmids of HBV and HDV were digested at $37^{\circ} \mathrm{C}$ with the restriction endonuclease Sau3AI. T4 DNA ligase was used to link gene fragments with universal adapters (SIP: 5'pGATCmCAC ACC AGC CAA ACC CA, SIR: 5'GGT TTG GCT GGT GTG). After $4 \mathrm{~h}$ of ligation at $16^{\circ} \mathrm{C}, 25 \mu \mathrm{l} 2 \times$ premix, $2 \mu \mathrm{l}$ of the linkage products, $2 \mu \mathrm{l}$ of the Cy5 labeled universal primer matched with the adaptor, and $21 \mu \mathrm{l}$ water were added to a total volume of $50 \mu \mathrm{l}$. Reactions were performed in a GeneAmp PCR 9700 system with an initial denaturation of $10 \mathrm{~min}$ at $94^{\circ} \mathrm{C}$, and then subjected to 30 thermal cycles $\left(94^{\circ} \mathrm{C}\right.$ for $30 \mathrm{~s}, 60^{\circ} \mathrm{C}$ for $30 \mathrm{~s}$, $72^{\circ} \mathrm{C}$ for $60 \mathrm{~s}$ ), followed by a final $5 \mathrm{~min}$ incubation at $72^{\circ} \mathrm{C}$. Finally, the reaction was stopped by cooling to $4^{\circ} \mathrm{C}$. After this labeling reaction, the sample DNA fragments of hundreds base pairs were labeled with fluorescent Cy5. The labeled PCR products were then further purified using a 3S PCR product purification kit V20 (Bocai Corp.). $5 \mu \mathrm{l}$ of the $30 \mu \mathrm{l}$ purified products was used for hybridization with the microarry probes.

Prehybridization Microarray slides were placed in a prehybridization solution $(5 \times \mathrm{SSC}, 0.2 \% \mathrm{SDS}, 25 \%$ formamide and $1 \% \mathrm{BSA}$ ) at $42^{\circ} \mathrm{C}$ for $1 \mathrm{~h}$, rinsed at room temperature in Milli Q water for 5 times, dehydrated in isopropanol, and air dried.

Hybridization and data analysis $5 \mu \mathrm{l}$ Cy5 labeled samples were mixed with $1 \mu \mathrm{l}$ Cot-1 DNA (20 $\mu \mathrm{g} / \mu \mathrm{l}$, Life Technologies) and $6 \mu \mathrm{l}$ $2 \times$ hybridization buffer ( $50 \%$ formamide, $10 \times \mathrm{SSC}, 0.2 \% \mathrm{SDS}$ ), and denatured at $95^{\circ} \mathrm{C}$ for $5 \mathrm{mins}$, centrifuged at $14,000 \mathrm{rpm}$ for 
Table 1. Sequences of the synthetic primers used for preparing the HBV and HDV probes

\begin{tabular}{|c|c|c|c|c|}
\hline Virus & No. & Primers $\left(5^{\prime} \rightarrow 3^{\prime}\right)$ & Location (nt) & Product size (bp) \\
\hline \multirow{10}{*}{$\mathrm{HBV}$} & 1 & $\begin{array}{l}\text { P1: ACTCGTGGTGGACTTCTCTC } \\
\text { P2: GAACCACTGAACAAATGGCA }\end{array}$ & $\begin{array}{l}251-270 \\
701-720\end{array}$ & $470 \mathrm{bp}$ \\
\hline & 2 & $\begin{array}{l}\text { P3: CATCTTCTTGTTGGTTCTTCTG } \\
\text { P4: TTAGGGTTCAAATGTATACCC }\end{array}$ & $\begin{array}{l}427-448 \\
840-860\end{array}$ & $434 \mathrm{bp}$ \\
\hline & 3 & $\begin{array}{l}\text { P5: CTGTGAGGAGTTGGGGGAGGAGATT } \\
\text { P6: GGCGAGGGAGTTCTTCTTCTAGGGG }\end{array}$ & $\begin{array}{l}1730-1754 \\
2397-2421\end{array}$ & $692 \mathrm{bp}$ \\
\hline & 4 & $\begin{array}{l}\text { P7: GGGTCACCATATTCTTGG } \\
\text { P8: CCCTGAGCCTGAGGGCTCCACC }\end{array}$ & $\begin{array}{l}2814-2831 \\
3080-3101\end{array}$ & $288 \mathrm{bp}$ \\
\hline & 5 & $\begin{array}{l}\text { P9: CTCCAGTTCAGGAACAGTAAACCC } \\
\text { P10: ATAACTGAAAGCCAAACAGTGGG }\end{array}$ & $\begin{array}{c}67-90 \\
744-766\end{array}$ & $700 \mathrm{bp}$ \\
\hline & 6 & $\begin{array}{l}\text { P11: ATTCCTATGGGAGTGGGCCTCAG } \\
\text { P12: GCAGCACAGCCTAGCAGCCATGG }\end{array}$ & $\begin{array}{c}779-801 \\
1407-1429\end{array}$ & $651 \mathrm{bp}$ \\
\hline & 7 & $\begin{array}{l}\text { P13: CCATACTGCGGAACTCCTAGC } \\
\text { P14: CAATGCTCAGGAGACTCTAAGGC }\end{array}$ & $\begin{array}{l}1409-1429 \\
2011-2033\end{array}$ & $625 \mathrm{bp}$ \\
\hline & 8 & $\begin{array}{l}\text { P15: GGAGCTACTGTGGAGTTACTCTC } \\
\text { P16: CTTCGTCTGCGAGGCGAGGG }\end{array}$ & $\begin{array}{l}1928-1950 \\
2350-2369\end{array}$ & $442 \mathrm{bp}$ \\
\hline & 9 & $\begin{array}{l}\text { P17: GGCAGGTCCCCTAGAAGAAGAACT } \\
\text { P18: TTGGGATTGAAGTCCCAATCTGG }\end{array}$ & $\begin{array}{l}2383-2406 \\
2960-2982\end{array}$ & $600 \mathrm{bp}$ \\
\hline & 10 & $\begin{array}{l}\text { P19: GGGGTGGAGCCCTCAGGCTCAGG } \\
\text { P20: CTGTAACACGAGAAGGGGTCCTAG }\end{array}$ & $\begin{array}{c}3072-3094 \\
134-157\end{array}$ & $300 \mathrm{bp}$ \\
\hline \multirow{4}{*}{ HDV } & 1 & $\begin{array}{l}\text { P1:GGAGACCGAAGCGAGGAGGAAAGCA } \\
\text { P2: CGACCTGGGCATCCGAAGGAGGACG }\end{array}$ & $\begin{array}{l}393-417 \\
843-867\end{array}$ & $475 \mathrm{bp}$ \\
\hline & 2 & $\begin{array}{l}\text { P3:CTGCAGGGTCCGCGTTCCATCCTT } \\
\text { P4:CCAGTGAATAAAGCGGGTTTC }\end{array}$ & $\begin{array}{l}697-720 \\
953-973\end{array}$ & $277 \mathrm{bp}$ \\
\hline & 3 & $\begin{array}{l}\text { P5: GACCCGAAGAGGAAAGAAGGACGC } \\
\text { P6: GGTGTGAACCCCCTCGAAGGTGG }\end{array}$ & $\begin{array}{c}896-919 \\
1143-1165\end{array}$ & $270 \mathrm{bp}$ \\
\hline & 4 & $\begin{array}{l}\text { P7:CTTCGTCGGTGATCCTGCCTCT } \\
\text { P8:CCAGCAGTCTCCTCTTTACAGA }\end{array}$ & $\begin{array}{l}631-652 \\
941-962\end{array}$ & $332 \mathrm{bp}$ \\
\hline
\end{tabular}

$2 \mathrm{~min}$, and cooled to room temperature. Three $\mu \mathrm{l}$ of the above mixture was then added to the surface of the microarray, which had been immersed in the prehybridisation medium for $1 \mathrm{~h}$, and covered with a glass coverslip pretreated with SIGMACOTE ${ }^{\circledR}$ (Sigma, St. Louis, USA) to prevent sample evaporation. The slide was placed in a sealed hybridization box; $10 \mu \mathrm{l}$ UPW was added to every well at the two ends of the chamber. After hybridization at $42^{\circ} \mathrm{C}$ for $5 \mathrm{~h}$, the slide was taken out and washed with: 1) low-stringency washing buffer containing $1 \times \mathrm{SSC} / 0.2 \%$ SDS at $42^{\circ} \mathrm{C}$ for $5 \mathrm{~min}$; 2) highstringency washing buffer containing $0.1 \times \mathrm{SSC} / 0.2 \% \mathrm{SDS}$ at room temperature for $10 \mathrm{~min}$; 3) $0.1 \times \mathrm{SSC}$ for $1 \mathrm{~min}$; 4) Milli Q water; 5) ethanol; respectively. The chip was then desiccated at room temperature. Scanning was performed using a ScanArray Lite Microarray Analysis System (GSI Lumonics Co).

\section{Results}

Preparation of $\mathrm{HBV}$ and HDV probes for the microarray
From the $1.5 \%$ agarose gel electrophoresis results, we found that that all the respective 10 and 4 primer pairs amplified HBV DNA and HDV cDNA and produced products of the expected size (Fig. 2, Fig. 3).

Confirmation of the DNA obtained from HBV and HDV by sequence analysis By using Blastn and the Genbank database, each sequenced PCR product was confirmed to be a HBV or HDV genome fragment. Fig. 4 and Fig. 5 show one DNA fragment from HBV located at the polymerase gene region and one cDNA fragment from HDV located at the complete genome region, respectively.

Microarray design The clinical diagnostic microarray was prepared by immobilizing the captured target genes of pathogens on a slide, which was treated specifically. The DNA or RNA extracted from the patient's serum was labeled with fluorochrome and hybridized to the target DNA. In this paper, the microarray was prepared by spotting PCR products of the 


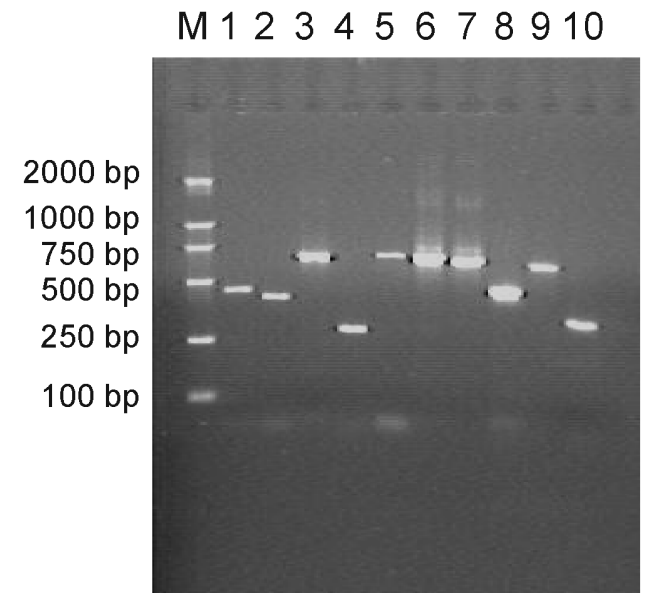

Fig. 2. Agarose gel electrophoresis of the PCR products of ten fragments by different primer combinations for to prepare the HBV genechip probes.

conserved sequences of HBV and HDV onto the surfaces of glass slides by using a Cartesian 5,500 MicroArrayer. Controls were immobilized at the same time. The control system was composed of three parts: (i) empty controls were DMSO without gene fragments, (ii) negative controls were gene fragments of plants (rice), an eukaryocyte (K562 cell), and a prokaryocyte (E. coli), which were not homologous with HBV and HDV, and (iii) positive controls were the reconstructed gene fragments. Ten of the $12 \times 12$ microarrays could be simultaneously immobilized on a glass slide.

\section{Analysis of the microarrays hybridized with $\mathrm{HBV}$ and} HDV DNA by fluorescent scanning From the hybridizing signals obtained using $80 \%$ laser energy and $70 \%$ GMT on the Gene chip, it was evident that it satisfied the specificity and sensitivity requirements for detecting HBV and HDV, as shown in Fig. 6. The single array shown in Fig. A was hybridized with a sample of HBV, Fig. B was hybridized with a sample of HDV, and Fig. C was hybridized with an

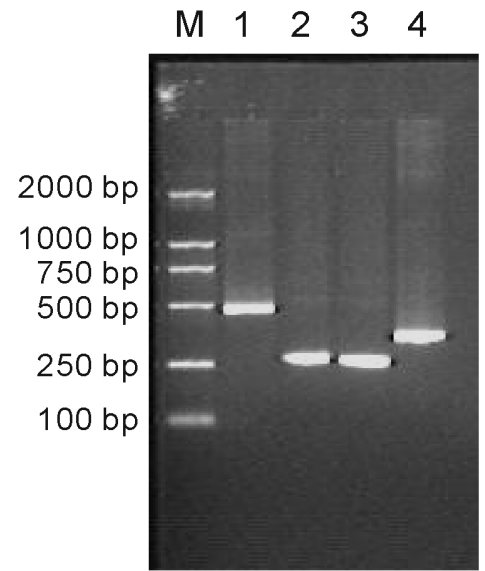

Fig. 3. Agarose gel electrophoresis of PCR products of four fragments using different primer combinations to prepare the HDV genechip probes.

admixture of HBV and HDV. No signal was observed on the empty control spots (Printing 50\% DMSO) or negative control spots (Printing gene fragments of eukaryotic cells such as K562 cell, prokaryotic cells such as HIV, and plant genes such as rice. Our institute preserved all gene fragments). The signals of spots hybridized to $\mathrm{HBV}, \mathrm{HDV}, \mathrm{HBV}$ positive controls, HDV positive controls, and an admixture of $\mathrm{HBV}$ and HDV were strong and obvious.

\section{Discussion}

In China, chronic viral hepatitis is considered a major public health problem. Approximately 150 million individuals have contracted chronic hepatitis B and the incidence rate of HBV infection is 158/1000,00 annually (Jin et al., 2001). Moreover, up to $40 \%$ of these individuals will eventually develop serious hepatic complications. HBV infection can cause acute and chronic liver disease including cirrhosis and HCC. The risk of

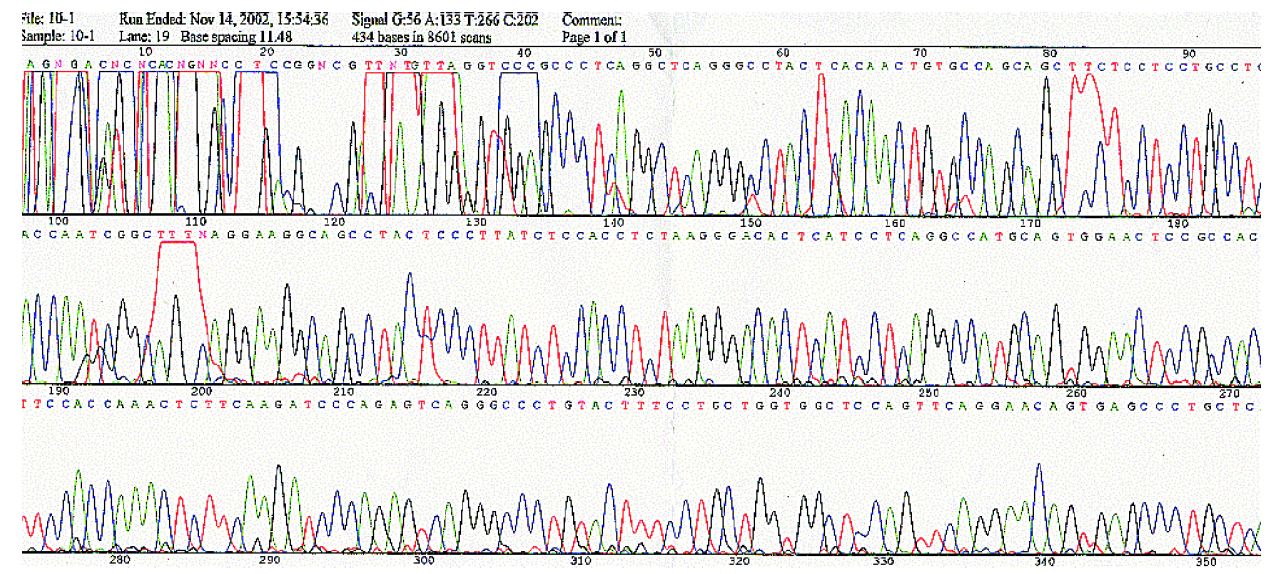

Fig. 4. Sequence analysis of one of the DNA fragments from HBV. 


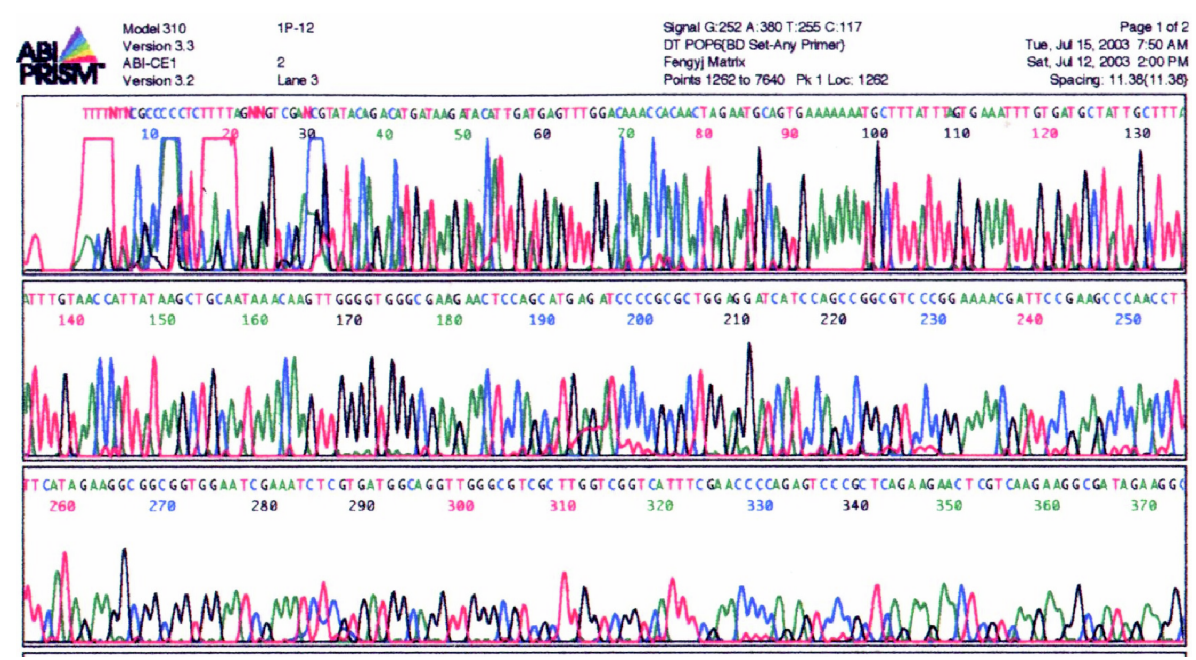

Fig. 5. Sequence analysis of one of the cDNA fragments from HDV.

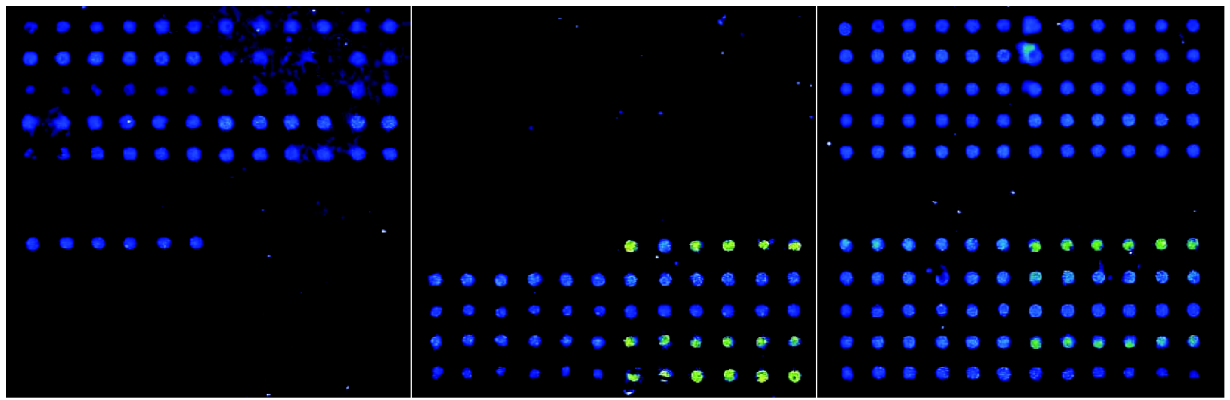

(A) Sample of HBV

(B) Sample of HDV

(C) Admixture of HBV and HDV

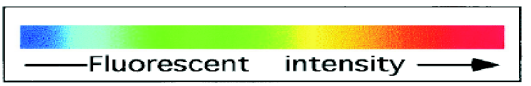

Fig. 6. Scanning results of hybridizing signals on Gene chip.

HCC in individuals that have developed chronic hepatitis B is 300 times higher than in normal people (Jin et al., 2001). The hepatitis D virus (HDV), a defective virus, requires the supply of hepatitis B surface antigen ( HbsAg) envelope by hepatitis B virus (HBV) for its assembly and transmission. During acute and chronic infection, and HDV infection often leads to more severe disease (Porres et al., 1989).

In the clinical diagnosis of hepatitis virus, antibody-based methods such as ELISA and molecular biologic techniques, such as PCR, and molecular hybridization had been considered practical ways of detecting viral infection. However, such immunoassays suffer from a problem because antibody assays are insufficient for diagnostic purposes due to the brief diagnostic window period and their inability to diagnose patients with hypoimmunity. For viral diagnosis, common nucleic acid hybridization may have a excellent specificity, but sensitivity requirements are not often satisfied. In the protocol of PCR, cross contamination, and the incidents of false negative and false positive often occur, and simply producing DNA provides to indication that the right product has been amplified. DNA microarrays offer a solution to these problems and provide us with a simple and sensitive method of diagnosing hepatitis virus infection. Compared with traditional diagnostic techniques, the technique has a number of obvious advantages-integration, micromation and automatization (Ma et al., 1999). In principle, one could draw on this resource when needed to clinically diagnose different hepatitis virus subtypes and the strain of drug resistance simultaneously on a microarray slide, and the captured DNA could be assayed in a single reaction. The DNA genechip also offers a dependable basis for clinical laboratory diagnosis, treatment, the monitoring of response to therapy, and the occurrence, development and prognosis of hepatotrophic viral infections (Petrik et al., 2001; Sun et al., 2003a, 2003b).

The chip we developed is cost-effective, and the procedure required to prepare the chip, straightforward and convenient. When results are verified by molecular hybridization, PCR cross contamination can be overcome, and by incorporating negative and positive controls, we detection results are ensured. Subjective factors in terms of judging results were 
reduced greatly by using analytic software (Falus et al., 1998). In addition, the sensitivity of the assay may be enhanced by increasing the amount of captured DNA on the slide or by pretreating the sample DNA.

There are two ways of preparing DNA microarray probes: the first one is the PCR amplification of the DNA fragments with a molecular clone, and the other is the artificial synthesis of oligonucleotide arrays using a DNA synthesizing machine. We preferred the first method, making use of Primer Premier 5.00 to design special $\mathrm{HBV}$ and HDV primers. While designing the primers, we tried to make the annealing temperatures of $\mathrm{HBV}$ and HDV coincide so that the PCR protocol could be performed easily in the same reaction system. Because of the convenience of PCR, we were able to directly prepare DNA microarray probes after purifying the PCR product. As for the small genome of $\operatorname{HBV}(3.2 \mathrm{~Kb})$ and HDV $(1.7 \mathrm{~Kb})$, the method is practical as it offers speedy, and simple clinical application.

Using Restriction Display-PCR RD-PCR (Ma et al., 1998; Zheng et al., 1998), Professor MA and ZHENG prepared microarray probes on a massive scale, which were nearly the same length, and developed diagnostic gene chips. Their method for preparing gene chip probes is used in our laboratory at present (Li et al., 2002; Mao et al., 2002; Zhu et al., 2002). Further applications of this technique for sample labeling could produce good results and speed up muti-virus detection by microarray technology (Feng et al., 2002; Zhang et al., 2002; Li et al., 2003). By RD amplification of the enzyme digested samples, the sample fragments can be significantly labeled with fluorescent signals, and can produce much stronger hybridizations than conventional labeling methods.

Acknowledgments We thank Dr. S. Gudima for the presentation of HDV plasmid and Dr. Zhang Bao and Shi Rong for critical technical assistance.

\section{References}

Falus, A., Varadi, A. and Rasko, I. (1998) The DNA chip, a new tool for medical genetics. Orv. Hetil. 139, 957-960.

Feng, C., Ma, W., Li, L., Song, Y., Shi, R.,Wu Q., Guo, Q., Zhu, J. and Zheng, W. (2002) Analysis with DNA chips of the changes of gene expressions in K562 cells in response to $\mathrm{As}_{2} \mathrm{O}_{3}$ treatment. J. First Mil. Med. Univ. 22, 772-774.

Jay, H. H. and Adrian, M. D. B. (1997) The treatment of chronic viral hepatitis. New Engl. J. Med. 336, 347-356.

Jin, Q. (2001) The hepatitis virus B; in The Medical Molecular Virology, Bi, S., Ceng, J. and Zhu, J. (eds.), pp. 325-326, Scientific Publishing, Beijing, P. R. China.

Li, L., Ma, W., Zhu, J., Zhu, L., Song, Y., Wu, Q., Guo, Q. and
Zheng, W. (2002) Preparation of HIV genechip probes by RDPCR technology. Chinese J. Biochem. Mol. Biol. 18, 105-109.

Li, L., Ma, W., Zhu, J., Shi, R., Liu, C., Chen, J. and Zheng, W. (2003) A modified restriction display PCR method in samplelabelling of DNA microarray. J. Virological Methods. 114, 7175.

Lok, A. S., Heathcote, E. J. and Hoofnagle, J. H. (2001) Management of hepatitis B: 2000-summary of a workshop. Gastroenterology 120, 1828-1853.

Ma, W. and Zheng, W. (1999) The research and development of DNA microarray technology. The Science Foundation of China. 13, 270-273.

Ma, W., Zheng, W. and James, F. B. (1998) RD-PCR: A new technique of differential display; in The Development of Biochemistry and Molecular Biology in PLA, Sun, Y. (ed.), pp. 99-113, Uniform Medical Publishing, Beijing, P. R. China.

Mao, X., Ma, W., Jiang, L. and Zheng, W. (2002) Application of restriction display PCR in preparing theprobes of the gene chip for investigating gene expression profile of K562 cells. J. First Mil. Med. Univ. 22, 548-553.

Petrik, J. (2001) Microarray technology:the future of blood testing? Vox Sanguinis. 80, 1-11.

Porres, J. C., Carreno, V., Bartolome, J., Moreno, A., Galiana, F. and Quiroga, J. A. (1989) Treatment of chronic delta infection with recombinant interferon alpha $2 \mathrm{c}$ at high doses. J. Hepatol. 9, 338-344.

Schena, M., Shalon, D., Davis, R. W. and Brown, P. O. (1995) Quantitative monitoring of gene expression patterns with a complementary DNA microarray. Science 270, 467-470.

Schena, M., Shalon, D., Heller, R., Chai, A., Brown, P. O. and Davis, R.W. (1996) Parallel human genome analysis :microarray-based expression monitoring of 1000 genes. Proc. Natl. Acad. Sci. USA 93, 10614-10619.

Shalon, D., Smith, S. J. and Brown, P. O. (1996) A DNA microarray system for analyzing complex DNA samples using two-color fluorescent probe hybridization. Genome Res. 6, 639645.

Sun, Z. H., Ma, W. and Zheng, W. (2003a) Microarrays development in the diagnosis of HBV and HCV. Med J. Chin. PLA 28, 375-376.

Sun, Z., Zheng, W. and Ma, W. (2003b) The development of molecular diagnosis of viral hepatitis. Guangdong Med. J. 24, 440-442.

Zhang, B., Ma, W., Hu, Z., Shi, R., Song, Y. and Zheng, W. (2002) A method for evaluation of the quality of DNA microarray spots. J. Biochem. Mol. Biol. 35, 532-535.

Zheng, W., Ma, W. and Waes, C. V. (1998) The differential display of poly A polymerase in tumor cells of differential malignancy; in Investigation on Cell Modulation, Ye, X. S. (ed.), pp. 73-79, Uniform Medical Publishing, Beijing, P. R. China.

Zhu, J., Ma, W., Li. L., Song, Y., Wu, Q.,Yao, L. and Zheng, W. (2002) Probes-preparation of cDNA microarray for the gene expression in leukemia K562 cell using restriction cDNA library. J. Res. Life Science 2, 142-146. 